\title{
Sepiolite as an effective supplement for low protein diets with the constant energyprotein ratio in broilers
}

sakine yalçın ( $\nabla$ sayalcin@ankara.edu.tr)

Ankara University Veterinary Faculty https://orcid.org/0000-0001-8640-2729

Emre Sunay Gebeş

Ankara Üniversitesi Veteriner Fakültesi: Ankara Universitesi Veteriner Fakultesi

Muhammad Shazaib Ramay

Ankara Üniversitesi Veteriner Fakültesi: Ankara Universitesi Veteriner Fakultesi

Oğuz Berk Güntürkün

Danisco US Inc Genencor Division: Dupont Industrial Biosciences

Suzan Yalçın

Selçuk Üniversitesi: Selcuk Universitesi

Ozan Ahlat

Ankara Üniversitesi Veteriner Fakültesi: Ankara Universitesi Veteriner Fakultesi

\section{Research Article}

Keywords: Broiler, digestibility, Intestinal histomorphology, Low protein-low energy diet, Meat quality, Performance, Sepiolite

Posted Date: February 3rd, 2022

DOI: https://doi.org/10.21203/rs.3.rs-1290837/v1

License: (c) (1) This work is licensed under a Creative Commons Attribution 4.0 International License. Read Full License 
1 Sepiolite as an effective supplement for low protein diets with the constant energy-

\section{Sakine Yalçın*1, Emre Sunay Gebeş ${ }^{1}$, Muhammad Shazaib Ramay ${ }^{1}$, Oğuz Berk} Güntürkün², Suzan Yalçın ${ }^{3}$, Ozan Ahlat ${ }^{4}$

${ }^{1}$ Department of Animal Nutrition and Nutritional Diseases, Faculty of Veterinary Medicine, Ankara University, Ankara, Turkey.

${ }^{2}$ Danisco Animal Nutrition, İstanbul, Turkey.

${ }^{3}$ Department of Food Hygiene and Technology, Faculty of Veterinary Medicine, Selçuk University, Konya, Turkey.

${ }^{4}$ Department of Pathology, Faculty of Veterinary Medicine, Ankara University, Ankara, Turkey.

Running Head: Sepiolite for low protein diets with the constant energy-protein ratio

*Corresponding author e-mail: $\underline{\text { sayalcin@ankara.edu.tr }}$ 


\section{Abstract}

The present study aimed to examine the influence of sepiolite on growth performance, meat quality, intestinal health, some blood parameters, and digestibility of nutrients in broilers fed low protein diets with the constant energy-protein ratio. A total of 252, daily male broiler chicks were allocated to four treatment groups further divided into 9 replicates each containing 7 chicks. Low protein diets having a constant energy-protein ratio were formulated by lowering protein and energy levels of the control group diet by 5\%. Sepiolite was used at the level of $1 \%$ in the diets. After 42 days trial total feed consumption, total body weight gain, total feed conversion ratio, and carcass yield were not influenced by reducing protein, sepiolite supplementation, and interaction between low protein-low energy diet and sepiolite. Reducing protein in the diets led to reducing the digestibility of nutrients, increasing ileal viscosity, decreasing villus height, villus surface area in duodenum and jejunum, and increasing abdominal fat, ether extract, cooking losses, total oxidant status, and oxidative status index in breast meat. Sepiolite supplementation to low protein diets increased crude protein digestibility, reduced viscosity, increased villus height/crypt depth values, reduced cooking losses, and increased water holding capacity. Blood serum biochemical parameters and minerals were not affected by sepiolite supplementation to low protein diets. Therefore, it is concluded that sepiolite can be added as a beneficial supplement in broiler diets as well as in low protein diets with a constant energy-protein ratio.

Key words: Broiler, digestibility; Intestinal histomorphology; Low protein-low energy diet; Meat quality; Performance; Sepiolite 


\section{Introduction}

Diet plays an important role in maintaining poultry health, growth performance, and production. Protein is the most expensive component and the second important nutrient in the diets of poultry. It is important to reduce the protein content of the diets in the poultry production industry to reduce the environmental pollution from nitrogen wastes to maintain sustainability in production. Environmental pollution from nitrogen excretion is a major problem in poultry houses and its results have adverse effects on the health of workers and poultry, soil, and groundwater (Kim et al. 2014; Chalova et al. 2016; Attia et al. 2020). Reducing protein in the diets decreases the undigested protein reaching the hindgut and thereby decreases the substrate available for infectious bacteria to proliferate. However, low protein diets with suboptimal amino acid supply have negative effects on performance in poultry (Aftab et al. 2006; Hilliar et al. 2020). Thus some strategies can be used to improve diet utilization, performance, and meat quality and decrease abdominal and subcutaneous fat in low protein diets (Suartika et al. 2014; Ndazigaruye et al. 2019; Gharib-Naseri et al. 2021). One of them may be sepiolite supplementation.

Sepiolite, a hydrated magnesium silicate $\left(\mathrm{Si}_{12} \mathrm{Mg}_{8} \mathrm{O}_{30}\left(\mathrm{OH}_{2}\right)_{4}(\mathrm{OH})_{4}\right)$ in the group of phyllosilicates (Sardi et al., 2004) is a feed additive in animal nutrition. The wide range of applications of sepiolite is based on its high absorption and adsorption capacity (Murray, 2000). It improves the performance of broilers and laying hens (Tortuero, 1982; Ouhida et al., 2000; Ayed et al., 2011; Eser et al., 2012; Yalçın et al., 2017). Sepiolite supplementation decreased the ileal (Yalçın et al., 2017) and jejunal (Ouhida et al., 2000) digesta viscosity and may reduce the antinutritional effects of diets having high viscosity which in turn improved the digestibility of nutrients, especially in fat and nitrogen balance (Yalçın et al., 2017). Pancreatic enzymes can be adsorbed to the surface of sepiolite forming active complexes at different digestive $\mathrm{pH}$ ranges (Cabezas et al., 1991). The enzyme-sepiolite complexes are resistant to proteolysis and in this 
way increase the active digestive enzymes in the gut. Cabezas et al. (1991) concluded that poultry fed with diets containing sepiolite will benefit from the feed more efficiently than the diets having no sepiolite. The most important point in terms of the welfare and nutrition of broilers is to reduce intestinal viscosity. This may have more beneficial under poor hygiene conditions or when fed low digestible diets. Sepiolite can improve gut health by promoting the activity of enzymes and/or binding harmful substances throughout the gut. However, no research was seen to investigate the sepiolite effects on broilers fed diets having low protein. Thus, this research was planned to investigate the effects of sepiolite supplementation to the low protein diets with a constant energy-protein ratio on the growth performance, digestibility of nutrients, carcass characteristics, meat quality, and blood parameters in broilers.

\section{Materials and method}

\section{Experimental design and diets}

Experimental procedures were approved by the Animal Ethics Committee of Ankara University (2013-5-39). This study involved 252 male one-day-old broiler chicks (Ross 308) which were allocated to 4 treatment groups that consisted of 9 replicates of 7 chicks. Each replicate was housed in pens $(90 \times 80 \times 80 \mathrm{~cm})$. As a litter, wood shavings were used in each pen. Water and mash feed were provided ad libitum for 6 weeks. The ingredients and chemical composition of experimental diets are shown in Table 1. Normal energy and normal protein (NPNE) diets were designed according to the recommendation of Ross 308 management manual (Aviagen, 2014) and all chicks were fed starter diets from 0 to 21 and grower diets from 22 to 42 days of age. Low protein-low energy diets (LPLE) were formulated by reducing protein and energy levels of NPNE diets by $5 \%$. Therefore, a constant energy-protein ratio was obtained. Sepiolite at the level of $1 \%$ was included in the diets of NPNE and LPLE to obtain the diets of sepiolite with NPNE (SNPNE) and sepiolite with LPLE (SLPLE) as shown in Table 1. Sepiolite was obtained 
from a private company (sepiolite, Exal TH, Tolsa Turkey, Eskişehir). Sepiolite consisted of $65 \%$ sepiolite, $9 \%$ attapulgite, $18 \%$ dolomite, $8 \%$ calcite. Sepiolite had $8.23 \%$ moisture and $89.87 \%$ ash. It had $2.6 \mathrm{mg} / \mathrm{kg} \mathrm{As}, 1.16 \mathrm{mg} / \mathrm{kg} \mathrm{Pb}, 0.02 \mathrm{mg} / \mathrm{kg} \mathrm{Hg}$ and less than $1 \mathrm{mg} / \mathrm{kg} \mathrm{Cd}$. Water holding capacity was higher than $150 \%$. A $5 \%$ of sepiolite particles were larger than $600 \mu, 40 \%$ is smaller than $250 \mu, 70 \%$ is smaller than $125 \mu$ and $7 \%$ is larger than $38 \mu$ in diameter.

\section{Traits measured}

The nutritional analysis of the diets was made according to the AOAC (2000). Metabolizable energy (ME) values of diets were estimated (Carpenter and Clegg, 1956).

At the beginning of the experiment and every week, the chicks were individually weighed. Body weight gains were determined from the differences between the weights of subgroups. Feed consumption was calculated weekly as a subgroup. Feed conversion ratio (FCR) was determined as $\mathrm{kg}$ feed consumed per $\mathrm{kg}$ weight gain.

On the 32nd day, one pen from each group was placed in the individual pen. Chromic oxide, as an indigestible indicator, at the level of $0.3 \%$ to the diets was added. Faeces were collected during a week. Feed and faeces samples were analyzed according to Williams et al. (1962) for the analysis of chromic oxide and then the content of chromium was determined using an optical emission spectrometer with inductively coupled plasma (ICP-OES, Varian Vista MPX CCD Simultaneous ICP-OES). Dry matter (procedure 930.15), crude protein using the Kjeldahl procedure (procedure 968.06) ash, and organic matter (procedure 942.05) were determined according to the AOAC (2000). Organic matter was calculated. The following formula was used to calculate the apparent total tract digestibility of nutrients:

$$
\mathrm{NATTD}=(1-((\mathrm{DC} * \mathrm{FN}) /(\mathrm{FC} * \mathrm{DN}))) * 100
$$


Where NATTD is the apparent total tract digestibility of nutrient (\%), DC is the content of chromium in the diet (\%), $\mathrm{FN}$ is the nutrient content of the faeces (\%), $\mathrm{FC}$ is the chromium content of the faeces (\%), DN is the nutrient content of the diet (\%)

These broilers were slaughtered after a week and ileum digesta was collected. Digesta was homogenized and centrifuged at $12.000 \times \mathrm{g}$ for $10 \mathrm{~min}$. The supernatant was used to determine the viscosity. The viscosity as centipoises (cPs) was measured (Graham et al., 1993) using a viscometer (model LVDV-I, Brookfield Digital Viscometer, Brookfield Engineering Laboratories Inc., Stoughton, MA).

One bird per replicate was evaluated for histomorphological analysis on day 42 (Onbaşılar et al., 2017). Duodenum, jejunum, and ileum segments of adequate length were removed, flushed with physiological saline solution, and submerged in a $10 \%$ formalin solution. Villus height $(\mathrm{VH})$, villus width (VW), crypt depth $(\mathrm{CD})$ were measured using a microscope (Olympus BX51-DP71, Tokyo, Japan) using Cellsens programs (CS-ST-V1.8) (Luna, 1968; Xu et al., 2003). A total of 10 well-oriented villus-crypt units/intestinal samples were randomly selected and measured. The ratio of villus height to crypt depth (VH/CD) and villus surface area $(\mathrm{VSA}=2 \pi \mathrm{x}(\mathrm{VW} / 2) \mathrm{x} \mathrm{VH})$ were calculated (Sakamoto et al., 2000; Çalık et al., 2019).

At the 42 nd of the trial, a total of 18 chicks from each group ( 2 broilers were randomly taken from each subgroup) were slaughtered. After slaughtering, hot carcass, liver, heart, kidney, spleen, bursa Fabricius, gizzard, and abdominal fat were weighed and percentages were determined by dividing carcass and organ weights by slaughtering weights. Left and right breast meat samples from each carcass were sliced properly. Right breast meat samples after one-day storage at $+4^{\circ} \mathrm{C}$ were used to determine water holding capacity (WHC) and cooking losses (CL) (Honikel, 1998). Left side samples of breast meat were stored at $-18^{\circ} \mathrm{C}$ until making analyses. Left breast meat samples were subjected to proximate analysis (AOAC, 2000). Catalase (CAT) enzyme activities (Goth, 1991), levels of total antioxidant (TAS, mmol Trolox equivalent/kg), 
and total oxidant (TOS, $\mu \mathrm{mol} \mathrm{H}_{2} \mathrm{O}_{2}$ equivalent $/ \mathrm{kg}$ ) in the left breast meat were measured with commercial kits (Rel Assay Diagnostics, Gaziantep, Turkey) by colorimetric methods (Erel, 2004; Erel, 2005). Oxidative stress index (OSI) values were determined with the following formula;

OSI $=(\mathrm{TOS}, \mu \mathrm{mol} / \mathrm{TAS}, \mu \mathrm{mol}) \times 100$ (Ramay and Yalçın, 2019)

On the last day of the experiment, blood samples were taken from 2 broilers from each subgroup and centrifuged at $3220 \times \mathrm{g}$ for $8 \mathrm{~min}$. Total protein, albumin, uric acid, triglyceride, and cholesterol in the blood serum were measured by an autoanalyzer (Product code 680-2153, Vitros 350; Johnson-Johnson Company, New York, USA) with commercial kits (Vitros Chemistry Products, Ortho-Clinical Diagnostics; Johnson-Johnson Company). Ca, P, Mg, Fe, $\mathrm{Cu}, \mathrm{Zn}, \mathrm{Na}$, and $\mathrm{K}$ in serum were determined using ICP-OES (Varian Vista MPX CCD Simultaneous ICP-OES).

\section{Statistical analysis}

Statistical analyses were done using the ANOVA method (SPSS INC., Chicago, IL, USA). Effects of energy-protein level and sepiolite were determined using two-way ANOVA. The significant differences among groups were analyzed by the Tukey test. The level of significance was taken as $\mathrm{P}<0.05$ (Dawson and Trapp, 2001).

\section{Results}

Inclusion of $1 \%$ sepiolite in low protein diets having a constant energy-protein ratio of broilers had no effect on feed intake, body weights, weight gains, and feed conversion ratios of groups during grower and whole of the six-weeks trial (Table 2). Feed intake of LPLE groups was increased and feed intake of sepiolite supplemented groups was reduced during the starter period. However, the FCR of groups was not affected by the changes in feed intake during the 
starter period. No interaction was seen between the dietary sepiolite and the dietary level of protein and energy in the present study.

Dietary sepiolite supplementation improved nutrient digestibility (Table 3). The 5\% reduction in energy and protein levels in diets significantly reduced the digestibility of nutrients. Sepiolite supplementation had higher nutrient digestibility in the NPNE diets and also LPLE diets, however, significant increments were seen only in the digestibility of crude protein. Reducing protein and energy levels in the diets having $1 \%$ sepiolite reduced digestibility of crude protein $(\mathrm{P}<0.05)$. The $5 \%$ reduction in energy and protein levels of diets increased ileum viscosity $(\mathrm{P}=0.05)$. However, sepiolite supplementation decreased ileum viscosity significantly $(\mathrm{P}<0.01)$ in both of the diets. Reducing protein and energy levels in the diets having $1 \%$ sepiolite did not affect ileum viscosity.

Sepiolite supplementation to the diets of broilers increased $\mathrm{VH}$ and $\mathrm{VH} / \mathrm{CD}$ in the duodenum, the jejunum, and the ileum, and VSA in the duodenum, significantly as shown in Table 4 . The $5 \%$ reduction in dietary energy and protein levels significantly reduced $\mathrm{VH}, \mathrm{CD}$, and VSA in the duodenum and jejunum and increased $\mathrm{VH} / \mathrm{CD}(\mathrm{P}<0.001)$. Lowering energy and protein levels in diets significantly reduced $\mathrm{CD}(\mathrm{P}<0.001)$, and increased $\mathrm{VH} / \mathrm{CD}(\mathrm{P}=0.001)$ in the ileum. Sepiolite addition to the NPNE diets did not cause any differences in intestinal histomorphological parameters. However, sepiolite addition to the LPLE diets increased VH, $\mathrm{VW}, \mathrm{VH} / \mathrm{CD}$, and $\mathrm{VSA}$, decreased $\mathrm{CD}$ in the duodenum, increased $\mathrm{VH} / \mathrm{CD}$ in the jejunum, and increased $\mathrm{VH}$ and $\mathrm{VH} / \mathrm{CD}$ in the ileum $(\mathrm{P}<0.05)$. Reducing protein and energy levels in the diets having $1 \%$ sepiolite reduced $\mathrm{VH}$ and $\mathrm{CD}$, increased $\mathrm{VW}, \mathrm{VH} / \mathrm{CD}$ in the duodenum, increased $\mathrm{VH} / \mathrm{CD}$ in the jejunum, and the ileum $(\mathrm{P}<0.05)$.

As given in Table 5, sepiolite supplementation did not affect the carcass yield and the relative weight percentages of heart, spleen, liver, gizzard, bursa Fabricius and abdominal fat. The 5\% reduction in dietary energy and protein levels caused a significant increase in the 
relative weight of abdominal fat percentage $(\mathrm{P}=0.024)$. The relative weight of liver percentage was not affected by only dietary energy-protein level or $1 \%$ sepiolite inclusion, but an interaction between dietary energy-protein level and sepiolite was found. In the groups fed the LPLE diet, the liver percentage was reduced with the addition of $1 \%$ sepiolite. However, these values in the LPLE group were not significantly different from that of the NPNE group.

As shown in Table 6, the 5\% reduction in dietary energy and protein levels decreased WHC $(\mathrm{P}<0.001)$, increased CL $(\mathrm{P}=0.052)$, decreased TAS $(\mathrm{P}=0.002)$, increased TOS $(\mathrm{P}=0.017)$, OSI $(\mathrm{P}<0.001)$, and ether extract percentages $(\mathrm{P}=0.047)$ in breast meat of broilers. Reducing energy and protein levels in diets did not affect the CAT enzyme activity and the percentages of dry matter, crude protein, and crude ash in breast meat. The WHC was increased $(\mathrm{P}=0.009)$ and $\mathrm{CL}$ was decreased $(\mathrm{P}=0.009)$ with dietary $1 \%$ sepiolite supplementation. Dietary sepiolite had no effects on oxidant-antioxidant status, CAT enzyme activity, and the proximate composition of breast meat.

Dietary sepiolite increased blood serum total protein and albumen, reduced total cholesterol and triglyceride, and did not affect uric acid, ALT, AST, ALP, and minerals as shown in Table 7 and Table 8 . The 5\% reduction in dietary energy and protein levels significantly reduced blood serum levels of albumin, total protein, total cholesterol, triglyceride, ALT, AST, and Ca (Table 7, Table 8). Sepiolite supplementation increased serum albumin concentration and decreased serum total cholesterol in the groups fed diets having normal energy and protein level. However, no change was observed in serum albumin and total cholesterol in the low energy and low protein diet. Reducing protein and energy levels in the diets having $1 \%$ sepiolite reduced serum albumin and cholesterol concentration. No significant effects were seen in serum levels of uric acid, ALP, $\mathrm{P}, \mathrm{Na}, \mathrm{K}, \mathrm{Mg}, \mathrm{Zn}, \mathrm{Cu}$, and Fe in this study.

\section{Discussion}


Sepiolite supplementation to normal or low protein diets having a constant energy-protein ratio in broilers did not affect performance values after the six-week trial. Similar to the present study results, some researchers reported that $1 \%$ (Ouhida et al., 2000), 1.5\% (Uzunoğlu and Yalçın, 2019) and 2\% (Ouhida et al., 2000; Yalçın et al., 2017) addition of sepiolite had no effects on these performance indices in broilers. However, the addition of sepiolite at the levels of $0.5 \%$ (Eser et al., 2012), 1\% (Ayed et al., 2011; Eser et al., 2012; Yalçın et al., 2017) and 2\% (Ayed et al., 2011) increased body weights and weight gains of broilers. Feed efficiency of broilers was improved with dietary usage of 1\% (Ayed et al, 2011; Yalçın et al, 2017) and 2\% (Ayed et al., 2011) sepiolite. Different results among the studies may be due to the numerous factors such as quality and doses of sepiolite, diet composition, water quality, and management conditions (Yalçın et al., 2017). Reducing energy and protein levels (constant energy-protein ratio) by $5 \%$ had no negative effects on performance indices during the present study. Kamran et al. (2008) stated that body weight gain was decreased and feed intake and FCR values were increased with the reduction in protein and energy levels having a constant energy-protein ratio in the diets during grower, finisher periods, and overall experimental periods, but these parameters were not affected during the starter period. On the contrary to the present study, some researchers (Hidalgo et al., 2004; Kamran et al., 2008) showed that feeding broiler chickens with low protein diets with a constant energy-protein ratio negatively affected the growth performance.

Sepiolite supplementation decreased ileal viscosity and increased digestibility in NPNE and also LPLE diets however significant increments were seen only in the digestibility of crude protein. This increase in digestibility did not contribute to the improvement in performance indices. This may be due to the short duration of the fattening period in broilers. Reducing protein levels in the diets having $1 \%$ sepiolite did not affect ileum viscosity but caused a 
reduction in the digestibility of crude protein $(\mathrm{P}<0.05)$. However, reduction in digestibility did not cause to decrease in body weight and weight gain significantly.

Similar to this present study, Yalçın et al. (2017) reported that 1\% sepiolite improved the digestibility of dry matter, organic matter, and crude protein in the ileum. Sepiolite may decrease the passage of nutrients and thus retain digesta longer, increasing the transit time of nutrients. Therefore, the ability of the digestive tract to hydrolyze dietary nutrients enzymatically, digestibility, and absorption of nutrients could be increased (Ayed et al., 2011; Ouhida et al., 2000; Tortuero et al., 1992; Perez-Vendrell et al., 2011) due to the sepiolite structure. Dietary sepiolite supplementation at $2 \%$ improved digestibility of energy and protein in weaned pigs by 5.3 and $6.1 \%$ (Parisini et al., 1999).

In the study of Ouhida et al. (2000) on the broiler chickens, sepiolite was added to diets with low, medium, and high viscosity values at 1 and $2 \%$ levels, the digestibility of organic matter increased due to the reduction in jejunum viscosity but the ileum viscosity was not affected by dietary sepiolite supplementation. Alzueta et al. (2002) stated that sepiolite (2\%) supplementation to the diets of broilers from 22 to 28 days of age did not affect either the digestibility of protein and fat and viscosity of digesta. Zhou et al. (2014) reported that clays increase the intestinal viscosity due to the formation of gel, which slows down the digesta passage rate. Therefore, an increased transit time of digesta may improve the endogenous enzyme activity and the digestibilities of nutrients (Ouhida et al., 2000).

Properties of intestinal morphology such as $\mathrm{VH}, \mathrm{VW}, \mathrm{CD}, \mathrm{VH} / \mathrm{CD}$, and VSA are important health indicators and reflect the digestive and absorptive capacity in the gut (Buddle and Bolton, 1992). Low protein diets significantly reduced VH, CD, and VSA and increased $\mathrm{VH} / \mathrm{CD}$ in duodenum and jejunum $(\mathrm{P}<0.001)$ and reduced $\mathrm{CD}(\mathrm{P}<0.001)$ and increased $\mathrm{VH} / \mathrm{CD}$ $(\mathrm{P}=0.001)$ in the ileum. Khosravinia et al (2015) reported that the improvement in digestion and absorption was correlated with the increase in the ratio of $\mathrm{VH} / \mathrm{CD}$. According to Allameh and 
Toghyani (2019), the ratio of VH/CD was a marker for the digestive capacity of the small intestine. Abd-Elsamee et al. (2020) indicated that the reduction in dietary protein content without change in energy level in the diet caused a significant reduction in $\mathrm{VH}, \mathrm{VW}, \mathrm{VW} / \mathrm{CD}$, and absorption area. Sepiolite supplementation to low protein diets increased VH, VW, VH/CD, and VSA and reduced $\mathrm{CD}$ in the duodenum, increased $\mathrm{VH} / \mathrm{CD}$ in the jejunum, and increased $\mathrm{VH}$ and $\mathrm{VH} / \mathrm{CD}$, in the ileum $(\mathrm{P}<0.05)$. SLPLE reduced $\mathrm{VH}$ and $\mathrm{CD}$, increased $\mathrm{VW}, \mathrm{VH} / \mathrm{CD}$ in the duodenum, increased VH/CD in the jejunum and the ileum $(\mathrm{P}<0.05)$. Similarly, Xia et al. (2004) and Awad et al. (2009) found that longer villi led to better performance when $\mathrm{Cu}$ montmorillonite was added to the diets. An improvement in villus height increases the surface area for nutrient absorption thereby increasing nutrient digestibility (Subramaniam and Kim, 2015). In the present study longer villi contributes to higher nutrient digestibility but did not improve performance indices. It can be thought that performance improvement may be seen in longer feeding periods as in turkey fattening or laying hen or in addition to other types or different doses of clay minerals. Yalçın et al. (2017) showed that 1\% sepiolite increased VH in the duodenum but did not affect jejunal and ileal histomorphology characteristics.

The main objectives of the poultry industry are to increase the carcass yield with the reduction of abdominal fat. Carcass yield and the relative weight percentages of internal organs were not influenced by sepiolite supplementation. The relative weight of abdominal fat percentage of the group fed diet having low protein with a constant energy-protein ratio was significantly increased $(\mathrm{P}=0.024)$. Excessive fat accumulation is an unfavorable trait for producers and consumers as it is considered as wasted energy in diets, reduces carcass yield, adversely affects consumer acceptance, and is a waste product with low economic value (Emmerson, 1997; Luca et al., 2004; Fouad and Senousey, 2014; Yalçın et al., 2017). Similarly reducing dietary protein levels caused an increase in the amount of abdominal fat (Kassim and Suwanpradit, 1996; Collin et al., 2003; Suartika et al, 2014). Kamran et al (2008) stated that 
carcass yield and relative organ weights were not affected by the reduction in the protein of diet having a constant energy-protein ratio in the diets. Some researchers (Eser et al., 2012; Yalçın et al., 2017; Uzunoğlu and Yalçın, 2019) also stated that sepiolite supplementation did not affect carcass yield, the relative weight percentages of heart, spleen, liver, and bursa of Fabricius. Similarly, the relative weight of abdominal fat percentage was not affected by $0.5 \%$ (Eser et al., 2012) and 1.5\% (Uzunoğlu and Yalçın, 2019) sepiolite. However, 1\% (Eser et al., 2012; Yalçın et al., 2017) and 2\% (Yalçın et al, 2017) sepiolite reduced abdominal fat percentages significantly. The reduction in abdominal and subcutaneous fat is a key factor for the success of poultry meat production (Zerehdaran et al., 2004). In this study, dietary $1 \%$ sepiolite reduced abdominal fat percentage by $14.17 \%$, but this reduction was not statistically significant.

Broiler meat is one of the main sources of filling animal protein gaps and can play an important role in maintaining a balanced diet. Cooking loss is a parameter relating to meat tenderness. Water loss decreases the nutritional value of meat because nutrients can be removed along with the exudate, resulting in a reduction of tenderness in meat (Yalçın et al., 2017). Poultry meat is susceptible to oxidation. Antioxidant enzymes are widely found in animal tissues and play an important role in removing ROS and thus may have important effects in reducing oxidative damage during reoxygenation (Moyo et al., 2012). The increase in total antioxidant activity protects against free radicals and peroxides (Gbore et al., 2021). Catalase is the important antioxidant enzyme and reduces oxidative stress by destroying the mechanism of cellular hydrogen peroxide to produce water and oxygen (Kopec et al., 2016). Catalase enzyme activity was increased in the jejunal mucosa by the supplementation of $2 \%$ clay product (zeolite-attapulgite) (Zhou et al., 2014) and in the liver by the supplementation of $2 \%$ clinoptilolite (Wu et al., 2013) in the broiler. However, in the present study sepiolite addition did not affect catalase enzyme activity in breast meat. 
Reducing protein with constant energy and protein led to decrease WHC $(\mathrm{P}<0.001)$, increase CL $(\mathrm{P}=0.052)$, decrease TAS $(\mathrm{P}=0.002)$, and increase TOS $(\mathrm{P}=0.017)$ and OSI $(\mathrm{P}<0.001)$ levels in the present study.

The $5 \%$ reduction in dietary energy and protein levels significantly reduced ether extract percentages $(\mathrm{P}=0.047)$ in breast meat of broilers. Castaing and Noblet (1997) $2 \%$ sepiolite supplementation reduced carcass fatness and an increase of muscle percentage in the carcass. Quachem and Kaboul (2012) stated that sepiolite may increase the use of proteins in muscle production and thus, reduce abdominal fat. Similarly, Yalçın et al. (2017) suggested that meat proximate composition was not affected significantly by 1 and $2 \%$ sepiolite supplementation. CL in the group fed diet supplemented with $1 \%$ sepiolite was decreased by $2 \%$ in the study of Yalçın et al. (2017).

Low protein diets having a constant energy-protein ratio led to reducing albumin, total protein, triglyceride, total cholesterol, ALT, AST and Ca in blood serum levels. Sepiolite supplementation to the LPLE diets decreased serum albumin and cholesterol concentration. Abd-Elsamee et al. (2020) stated that low protein diets without any change in energy level in the diet did not affect serum AST and uric acid while a reduction in albumin and total protein levels. Yalçın et al. (2017) concluded that 1 and 2\% sepiolite supplementation did not influence the serum levels of calcium, phosphorus, magnesium, potassium, sodium, zinc, iron, protein, albumin, and uric acid but triglyceride and cholesterol levels were decreased. Mizrak et al. (2014) also found that 1.5 and $3 \%$ sepiolite in the diets of laying hens did not influence the serum levels of cholesterol, albumin, protein, phosphorus, and calcium. Fernandez et al. (1994) stated that 1.25 and $1.75 \%$ sepiolite had no effect on plasma levels of $\mathrm{P}, \mathrm{Ca}, \mathrm{K}$, and $\mathrm{Na}$ but $2.25 \%$ sepiolite increased plasma levels of $\mathrm{Ca}, \mathrm{P}$, and $\mathrm{K}$, and reduced $\mathrm{Mg}$ but didn't affect $\mathrm{Na}$ and $\mathrm{Cl}$. On the contrary to the present study, Tortuero and Rioperez (1989) reported that sepiolite supplementation to the diets of growing pigs increased serum levels of zinc. 
As a result, supplementation of sepiolite to low protein (5\% reduction) diets with a constant energy-protein ratio increased the nutrient digestibility, improved breast meat quality, intestinal histomorphology, and reduced viscosity without any negative effects on performance and carcass traits in broilers. Further study is proposed to clarify the mechanisms involved in the use of sepiolite to improve the nutritive value of diets having different protein and energy levels.

Author contribution All authors contributed to the study conception, design, material preparation, and data collection. Data analysis, writing review, and editing the last draft of the manuscript were performed by Sakine Yalçın, Suzan Yalçın and Muhammad Shazaib Ramay. All authors read and approved the manuscript.

Acknowledgements The authors wish to thank Tolsa Turkey for supplying sepiolite and Beypiliç for supplying chicks.

Funding This work was supported by the Ankara University Scientific Research Projects Coordination Unit (Project No: 13B3338009).

\section{Declarations}

Ethical standards This study was approved by the Animal Ethics Committee of Ankara University (2013-5-39).

Conflict of Interest The authors declare that they have no conflict of interest. The manuscript has been read and approved by all named authors and that there are no other persons who satisfied the criteria for authorship but are not listed. 
Data availabilitry statement: Data will be made available on reasonable request from the corresponding author.

\section{References}

Abd-Elsamee M.O., Motawe H.F.A., Selim M.M., Elsherif H.M.R. 2020. Effect of different dietary crude protein levels and citric acid on broiler chickens' performance, carcass characteristics, intestinal morphology and blood components. World's Veterinary Journal, 10: 362-374.

Aftab U., Ashraf M., Jiang Z. 2006. Low protein diets for broilers. World's Poultry Science Journal, 62: 688-701.

Allameh, S., Toghyani, M. 2019. Effect of dietary valine supplementation to low protein diets on performance, intestinal morphology and immune responses in broiler chickens. Livestock Science, 229:137-144.

Alzueta C., Ortiz L.T., Rebole A., Rodriguez M.L., Centeno C., Trevino J. 2002. Effects of removal of mucilage and enzyme or sepiolite supplement on the nutrient digestibility and metabolyzable energy of a diet containing linseed in broiler chickens. Animal Feed Science and Technology, 97: 169-181.

AOAC. 2000. Official Methods of Analysis of the Association of Official Analytical Chemists. 17th ed., AOAC International, Maryland, USA.

Attia Y.A., Bovera F., Wang J., Al-Harthi M.A., Kim W.K. 2020. Multiple amino acid supplementations to low-protein diets: Effect on performance, carcass yield, meat quality and nitrogen excretion of finishing broilers under hot climate conditions. Animals, 10:973: doi:10.3390/ani10060973.

Aviagen, 2014. Ross Broiler Management Handbook. Huntsville, AL, Aviagen Group. 
Awad W.A., Ghareeb K., Abdel-Raheem S., Böhm J., 2009. Effects of dietary inclusion of probiotic and symbiotic on growth performance, organ weights and intestinal histomorphology of broiler chickens. Poultry Science, 88: 49-56.

Ayed M.H., Zghal I., Rekik B. 2011. Effect of sepiolite supplementation on broiler growth performances and carcass yield. Research Opinions in Animal and Veterinary Sciences, 1: $375-378$.

Buddle J.R., Bolton J.R. 1992. The pathophysiology of diarrhoea in pigs. Pig News Info, 13: $41 \mathrm{~N}-45 \mathrm{~N}$.

Cabezas M.J., Salvador D., Sinisterra J.V. 1991. Stabilization-activation of pancreatic enzymes adsorbed on to a sepiolite clay. Journal of Chemical Technology and Biotechnology, 52: 265-274.

Carpenter K., Clegg K. 1956. The metabolizable energy of poultry feeding stuffs in relation to their chemical composition. Journal of the Science of Food and Agriculture, 7: 45-51.

Castaing J., Noblet J. 1997. Effect of addition of sepiolite on digestive utilization of feed and performance in growing pigs. Journees de la Recherche Porcine en France, 29: 213220.

Chalova V.I., Kim J.H., Patterson P.H., Ricke S.C., Kim W.K. 2016. Reduction of nitrogen excretion and emissions from poultry: A review for conventional poultry. World's Poultry Science Journal, 72: 509-520.

Collin A., Malheiros R.D., Moraes V.M.B., Van As P., Darras V.M., Taouis M., Decuypere E., Buyse J. 2003. Effects of dietary macronutrient content on energy metabolism and uncoupling protein mRNA expression in broiler chickens. British Journal of Nutrition, 90: 261-269.

Çalık A., Yalçın S., Küçükersan S., Saçaklı P., Yıldız G., Ramay M.S., Ahlat O., Erbay Elibol F.K., Taban S. 2019. Effects of calcium soaps of animal fats on performance, abdominal 
fat fatty acid composition, bone biomechanical properties, and tibia mineral concentration of broilers. Kafkas Üniversitesi Veteriner Fakültesi Dergisi, 25: 61-70.

Dawson B., Trapp R.G. 2001. Basic and Clinical Biostatistics, (third ed.). Lange Medical Books/McGraw-Hill Medical Publishing Division, New York.

Emmerson D.A. 1997. Commercial approaches to genetic selection for growth and feed conversion in domestic poultry. Poultry Science, 76: 1121-1125.

Erel O. 2004. A novel automated method to measure total antioxidant response against potent free radical reactions. Clinical Biochemistry, 37: 112-119.

Erel O. 2005. A new automated colorimetric method for measuring total oxidant status. Clinical Biochemistry, 38: 1103-1111.

Eser H., Yalçın S., Yalçın S., Şehu A. 2012. Effects of sepiolite usage in broiler diets on performance, carcass traits and some blood parameters. Kafkas Üniversitesi Veteriner Fakültesi Dergisi, 18: 313-318.

Fernandez E., Tortuero F., Martin L. 1994. The effects of different levels of dietary sepiolite on tibial dyschondroplasia in chickens. Archiv für Geflügelkunde, 58: 171-175.

Fouad A.M., El-Senousey H.K. 2014. Nutritional factors affecting abdominal fat deposition in poultry: A review. Asian-Australasian Journal of Animal Sciences, 27, 1057-1068.

Gbore F.A., Oloruntola O.D., Adu O.A., Olarotimi O.J., Falowo A.B., Afolayan E.O. 2021. Serum and meat antioxidative status of broiler chickens fed diets supplemented with garlic rhizome meal, moringa leaf meal and their composite. Tropical Animal Health and Production, 53: 26.

Gharib-Naseri K., Dorigam J.C.P., Doranalli K., Morgan N., Swick R.A., Choct M., Wu S.B. 2021. Bacillus amyloliquefaciens CECT 5940 improves performance and gut function in broilers fed different levels of protein and/or under necrotic enteritis challenge. Animal Nutrition, 7: 185-197. 
Goth L. 1991. A simple method for determination of serum catalase activity and revision of reference range. Clinica Chimica Acta, 196: 143-152.

Graham H., Bedford M., Choct M. 1993. High gut viscosity can reduce poultry performance. Feedsuffs, 65: 14-15.

Hidalgo M.A., Dozier III W.A., Davis A.J., Gordon R.W. 2004. Live performance and meat yield responses to progressive concentrations of dietary energy maintained at a constant metabolizable energy-to-crude protein ratio. Journal of Applied Poultry Research, 13: 319-327.

Hilliar M., Hargreave G., Girish C., Barekatain R., Wu S-B., Swick R. 2020. Using crystalline amino acids to supplement broiler chicken requirements in reduced protein diets. Poultry Science, 99: 1551-1563.

Honikel K.O. 1998. Reference methods for the assessment of physical characteristics of meat. Meat Science, 49: 447-457.

Kamran Z., Sarwar M., Nisa M., Nadeem M.A., Mahmood S., Babar M.E., Ahmed S. 2008. Effect of low-protein diets having constant energy-to-protein ratio on performance and carcass characteristics of broiler chickens from one to thirty-five days of age. Poultry Science, 87: 468-474.

Kassim H., Suwanpradit S. 1996. The effects of dietary protein levels on the carcass composition of starter and grower broilers. Asian Australasian Journal of Animal Science, 9: 261-266.

Khosravinia H., Nourmohammadi R., Afzali N. 2015. Productive performance, gut morphometry, and nutrient digestibility of broiler chicken in response to low and high dietary levels of citric acid. Journal of Applied Poultry Research, 24: 470-480. 
Kim J.H., Patterson P.H., Kim W.K. 2014. Impact of dietary crude protein, synthetic amino acid and keto acid formulation on nitrogen excretion. International Journal of Poultry Science, 13: 429-436.

Kopec W., Wiliczkiewicz A., Jamroz D., Biazik E., Pudlo A., Hikawczuk T., Skiba T., Korzeniowska M. 2016. Antioxidant status of turkey breast meat and blood after feeding a diet enriched with histidine. Poultry Science, 95: 53-61.

Luca S., Giovanna M., Fernando E., Paola P. 2004. The effects of sepiolite-SPLF on piglet and heavy pig production. Italian Journal of Animal Science, 3: 225-234.

Luna L.G., 1968. Manual of histologic staining methods of the Armed Forces Institute of Pathology. Newyork: McGraw-Hill Book Co.

Mızrak C., Yenice E., Kahraman Z., Tunca M., Yıldırım U., Ceylan N. 2014. Effects of dietary sepiolite and mannanoligosaccharide supplementation on the performance, egg quality, blood and digestion characteristics of laying hens receiving aflatoxin in their feed. Ankara Üniversitesi Veteriner Fakültesi Dergisi, 61: 65-71.

Moyo B., Oyedemi S., Masika P.J., Muchenje V. 2012. Polyphenolic content and antioxidant properties of Moringa oleifera leaf extracts and enzymatic activity of liver from goats supplemented with Moringa oleifera leaves/sunflower seed cake. Meat Science, 91: 441447.

Murray H.H. 2000. Traditional and new applications for kaolin, smectite, and palygorskite: a general overview. Applied Clay Science, 17: 207-221.

Ndazigaruye G., Kim D-H., Kang C-W., Kang K-R., Joo Y-J., Lee S-R., Lee K-W. 2019. Effects of low-protein diets and exogenous protease on growth performance, carcass traits, intestinal morphology, cecal volatile fatty acids and serum parameters in broilers. Animals, 9: 226. 
Onbaşılar E., Kahraman M., Ahlat O., Güngör Ö., Çalık A., Taban S., Yalçın S. 2017. Differences in egg nutrient availability and embryo development in white layer breeder genotypes. Poultry Science, 96: 3600-3607.

Ouhida I., Perez J.F., Gasa J., Puchal F. 2000. Enzymes ( $\beta$-glucanase and arabinoxylanase) and/or sepiolite supplementation and the nutritive value of maize-barley-wheat based diets for broiler chickens. British Poultry Science, 41: 617-624.

Parisini P., Martelli G., Sardi L., Escribano F. 1999. Protein and energy retention in pigs fed diets containing sepiolite. Animal Feed Science and Technology, 79: 155-162.

Perez-Vendrell A.M., Barbera J.B., Escribano F. 2011. Use of a sepiolite in feeds to improve pellet quality and broiler performance. In: $18^{\text {th }}$ European Symposium on Poultry Nutrition. October 31-November 04, 2011, P106, Çeşme-İzmir, Turkey.

Quachem D., Kaboul N. 2012. The marl as a natural supply on broiler chicken feed: effects on the starter performance, the abdominal fat and the dropping moisture. International Journal of Poultry Science, 11: 225-228.

Ramay M.S., Yalçın S. 2020. Effects of supplemental pine needles powder (Pinus brutia) on growth performance, breast meat composition, and antioxidant status in broilers fed linseed oil-based diets. Poultry Science, 99, 479-486.

Sakamoto K., Hirose H., Onizuka A., Hayashi M., Futamura N., Kawamura Y., Ezaki T. 2000. Quantitative study of changes in intestinal morphology and mucus gel on total parenteral nutrition in rats. Journal of Surgical Research, 94: 99-106.

Sardi L., Martelli G., Escribano F., Parazza P., Parisini P. 2004. The effects of sepiolite-SPLF on piglet and heavy pig production. Italian Journal of Animal Science, 3: 225-234.

Suartika I.G., Sumadi I., Bidura I. 2014. Effect of probiotic supplementation on low protein diet on broiler performance. E-Journal of Animal Science of Uday University, 3: 1-10. 
Subramaniam M.D., Kim I.H. 2015. Clays as dietary supplements for swine: A review. Journal of Animal Science and Biotechnology, 6: 38. Doi:10.1186/s40104-015-0037-9.

Tortuero F. 1982. Effects of dietary sepiolite on the growth and food efficiency in broilers. Avances en Alimentacion y Mejora Animal, 9: 387-390.

Tortuero F., Fernandez Gonzalez E., Martin M.L. 1992. Effects of dietary sepiolite on the growth, visceral measurements and food passage in chickens. Archivos de Zootecnia, 41: 209-217.

Tortuero F., Rioperez J. 1989. Utilizacion de sepiolita en dietas para cerdos. Asociacion Nacional de Porcinocultura Cientifica, 84: 30-33.

Uzunoğlu K., Yalçın S. 2019. Effects of dietary supplementation of betaine and sepiolite on performance and intestinal health in broilers. Ankara Üniversitesi Veteriner Fakültesi Dergisi, 66: 221-229.

Xu Z.R., Hu C.H., Xia M.S., Zhan X.A., Wang M.Q. 2003. Effects of dietary fructooligosaccharide on digestive enzyme activities, intestinal microflora and morphology of male broilers. Poultry Science, 82: 1030-1036.

Williams C.H., David D.J., Lismaa O. 1962. The determination of chromic oxide in faeces samples by atomic absorption spectrophotometry. Journal of Agricultural Sciences, 59: 381-385.

Wu Y., Wu Q., Zhou Y., Ahmad H., Wang T. 2013. Effects of clinoptilolite on growth performance and antioxidant status in broilers. Biological Trace Element Research, 155: $228-235$.

Yalçın S., Yalçın S., Gebeş E.S., Şahin A., Duyum H.M., Escribano F., Ceylan A. 2017. Sepiolite as a feed supplement for broilers. Applied Clay Science, 148: 95-102. 
Zerehdaran S., Vereijken A.L.J., Van Arendonk J.A.M., Van Der Waaij E.H. 2004. Estimation of genetic parameters for fat deposition and carcass traits in broilers. Poultry Science, 83: 521-525.

Zhou P., Tan Y.Q., Zhang L., Zhou Y.M., Gao F., Zhou G.H. 2014. Effects of dietary supplementation with the combination of zeolite and attapulgite on growth performance, nutrient digestibility, secretion of digestive enzymes and intestinal health in broiler chickens. Asian Australasian Journal of Animal Science, 27: 1311-1318. 
Table 1 Ingredients and chemical analysis of diets (as-fed basis)

\begin{tabular}{|c|c|c|c|c|c|c|c|c|}
\hline \multirow[b]{2}{*}{ Ingredients (\%) } & \multicolumn{4}{|c|}{ Broiler Starter (0-3 week) } & \multicolumn{4}{|c|}{ Broiler Grower (4-6 week) } \\
\hline & \multicolumn{2}{|c|}{$\begin{array}{l}\text { Normal Energy } \\
\text {-Normal Protein }\end{array}$} & \multicolumn{2}{|c|}{$\begin{array}{l}\text { Low Energy - } \\
\text { Low Protein }\end{array}$} & \multicolumn{2}{|c|}{$\begin{array}{l}\text { Normal Energy - } \\
\text { Normal Protein }\end{array}$} & \multicolumn{2}{|c|}{$\begin{array}{l}\text { Low Energy - } \\
\text { Low Protein }\end{array}$} \\
\hline Sepiolite & - & + & - & + & - & + & - & + \\
\hline Corn & 49.23 & 46.83 & 57.78 & 55.00 & 52.10 & 49.55 & 59.85 & 57.20 \\
\hline Soybean meal & 20.90 & 19.00 & 27.00 & 24.00 & 15.65 & 13.35 & 14.10 & 11.30 \\
\hline Fullfat soya & 22.60 & 25.70 & 9.00 & 13.78 & 23.00 & 26.75 & 20.18 & 24.63 \\
\hline $\begin{array}{l}\text { Poultry } \\
\text { meal }\end{array}$ & 2.00 & 2.00 & 2.00 & 2.00 & 2.00 & 2.00 & 2.00 & 2.00 \\
\hline Sepiolite & 0 & 1.00 & 0 & 1.00 & 0 & 1.00 & 0 & 1.00 \\
\hline Soy oil & 1.20 & 1.40 & 0 & 0 & 3.50 & 3.60 & 0 & 0 \\
\hline Limestone & 1.30 & 1.30 & 1.30 & 1.30 & 1.15 & 1.15 & 1.15 & 1.15 \\
\hline Dicalcium phosphate & 1.90 & 1.90 & 1.90 & 1.90 & 1.85 & 1.85 & 1.85 & 1.85 \\
\hline Salt & 0.25 & 0.25 & 0.25 & 0.25 & 0.25 & 0.25 & 0.25 & 0.25 \\
\hline Sodium bicarbonate & 0.10 & 0.10 & 0.10 & 0.10 & 0.10 & 0.10 & 0.10 & 0.10 \\
\hline DL- methionine & 0.17 & 0.17 & 0.19 & 0.19 & 0.15 & 0.15 & 0.17 & 0.17 \\
\hline Lysine & 0.15 & 0.15 & 0.28 & 0.28 & 0.10 & 0.10 & 0.20 & 0.20 \\
\hline $\begin{array}{l}\text { Vitamin } \\
\text { premix }^{1}\end{array}$ & 0.15 & 0.15 & 0.15 & 0.15 & 0.15 & 0.15 & 0.15 & 0.15 \\
\hline Anticoccidial $^{2}$ & 0.05 & 0.05 & 0.05 & 0.05 & 0 & 0 & 0 & 0 \\
\hline \multicolumn{9}{|c|}{ Chemical composition (analyzed) } \\
\hline $\mathrm{ME}^{3}(\mathrm{kcal} / \mathrm{kg})$ & 3026 & 3020 & 2887 & 2890 & 3202 & 3200 & 3044 & 3048 \\
\hline Crude protein $(\mathrm{g} / \mathrm{kg})$ & 220.3 & 220.2 & 209.7 & 209.8 & 200.1 & 200.2 & 190.3 & 190.3 \\
\hline $\begin{array}{l}\mathrm{ME} / \mathrm{CP} \text { (kcal ME/g } \\
\mathrm{CP})\end{array}$ & 137.4 & 137.2 & 137.7 & 137.8 & 160.0 & 159.9 & 160.0 & 160.2 \\
\hline Calcium $(\mathrm{g} / \mathrm{kg})$ & 10.58 & 10.60 & 10.44 & 10.47 & 9.76 & 9.79 & 9.67 & 9.70 \\
\hline $\begin{array}{l}\text { Total phosphorus } \\
(\mathrm{g} / \mathrm{kg})\end{array}$ & 7.30 & 7.29 & 7.16 & 7.17 & 6.99 & 6.96 & 6.94 & 6.94 \\
\hline
\end{tabular}

': Supplied the following $1.5 \mathrm{~kg}$ of diet:: $9.000 .000 \mathrm{IU}$ vitamin $\mathrm{A}, 4.000 .000$ vitamin $\mathrm{D}_{3}, 50.000 \mathrm{mg}$ vitamin $\mathrm{E}, 2.000 \mathrm{mg}$ vitamin $\mathrm{K}_{3}, 2.000 \mathrm{mg}$ vitamin $\mathrm{B}_{1}, 5.000 \mathrm{mg}$ vitamin $\mathrm{B}_{2}, 40.000 \mathrm{mg}$ niacin, $15.000 \mathrm{mg}$ calcium $\mathrm{D}$ pantothenate, $2.000 \mathrm{mg}$ vitamin $\mathrm{B}_{6}, 10 \mathrm{mg}$ vitamin $\mathrm{B}_{12}, 1.500 \mathrm{mg}$ folic acid, $100 \mathrm{mg}$ D-biotin, $120.000 \mathrm{mg} \mathrm{Mn}, 40.000 \mathrm{mg} \mathrm{Fe}, 100.000 \mathrm{mg} \mathrm{Zn,} 16.000$ $\mathrm{mg} \mathrm{Cu}, 1.250 \mathrm{mg} \mathrm{I}, 200 \mathrm{mg} \mathrm{Co}, 300 \mathrm{mg} \mathrm{Se}, 125.000 \mathrm{mg}$ antioxidant (Etoksiquin, BHA).

2: Salinomycin

3: Calculated (Carpenter and Clegg, 1956) 
Table 2 Effect of addition of sepiolite on low energy low protein diets on performance values in broilers

\begin{tabular}{|c|c|c|c|c|c|c|c|c|c|c|c|c|}
\hline $\begin{array}{l}\text { EP } \\
\text { level }\end{array}$ & $\begin{array}{c}\text { Sepiolite } \\
(\%)\end{array}$ & $\begin{array}{c}\text { IBW } \\
(\mathrm{g})\end{array}$ & $\begin{array}{c}\text { FBW } \\
(\mathrm{g})\end{array}$ & $\begin{array}{c}\text { BWG } \\
1-3 \mathrm{w} \\
(\mathrm{g})\end{array}$ & $\begin{array}{c}\text { BWG } \\
4-6 \mathrm{w}(\mathrm{g})\end{array}$ & $\begin{array}{c}\text { BWG } \\
1-6 \mathrm{w}(\mathrm{g})\end{array}$ & $\begin{array}{c}\text { FI } \\
1-3 \mathrm{w}(\mathrm{g})\end{array}$ & $\begin{array}{c}\text { FI } \\
4-6 \mathrm{w} \\
(\mathrm{g})\end{array}$ & $\begin{array}{c}\text { FI } \\
1-6 \mathrm{w}(\mathrm{g})\end{array}$ & $\begin{array}{l}\text { FCR } \\
1-3 \mathrm{w} \\
(\mathrm{g} / \mathrm{g})\end{array}$ & $\begin{array}{c}\text { FCR } \\
4-6 \mathrm{w} \\
(\mathrm{g} / \mathrm{g})\end{array}$ & $\begin{array}{c}\text { FCR } \\
1-6 \mathrm{w} \\
(\mathrm{g} / \mathrm{g})\end{array}$ \\
\hline Normal & & 44.5 & 2.951 & 781 & 2.126 & 2.907 & 1.097 & 3.510 & 4.607 & 1.41 & 1.65 & 1.50 \\
\hline \multirow[t]{3}{*}{ Low } & & 44.3 & 2.935 & 794 & 2.089 & 2.891 & 1.133 & 3.552 & 4.684 & 1.43 & 1.70 & 1.62 \\
\hline & 0 & 44.4 & 2.972 & 791 & 2.136 & 2.928 & 1.128 & 3.554 & 4.683 & 1.43 & 1.67 & 1.60 \\
\hline & 1 & 44.4 & 2.915 & 784 & 2.078 & 2.870 & 1.102 & 3.508 & 4.609 & 1.41 & 1.68 & 1.61 \\
\hline Normal & 0 & 44.7 & 2.992 & 784 & 2.164 & 2.947 & 1.099 & 3.536 & 4.635 & 1.40 & 1.63 & 1.57 \\
\hline Normal & 1 & 44.4 & 2.911 & 779 & 2.088 & 2.867 & 1.095 & 3.485 & 4.579 & 1.41 & 1.67 & 1.60 \\
\hline Low & 0 & 44.0 & 2.952 & 799 & 2.109 & 2.908 & 1.158 & 3.573 & 4.730 & 1.45 & 1.70 & 1.63 \\
\hline Low & 1 & 44.5 & 2.919 & 789 & 2.069 & 2.874 & 1.108 & 3.531 & 4.639 & 1.41 & 1.70 & 1.62 \\
\hline \multicolumn{2}{|r|}{ SEM } & 0.16 & 14.87 & 4.53 & 14.38 & 14.91 & 5.93 & 17.92 & 21.27 & 0.01 & 0.01 & 0.01 \\
\hline \multicolumn{13}{|c|}{ P-value } \\
\hline & EP level & 0.391 & 0.596 & 0.162 & 0.226 & 0.604 & 0.005 & 0.253 & 0.077 & 0.217 & 0.083 & 0.061 \\
\hline & Sepiolite & 0.770 & 0.063 & 0.434 & 0.059 & 0.064 & 0.031 & 0.204 & 0.095 & 0.233 & 0.517 & 0.761 \\
\hline & level*Sepiolite & 0.153 & 0.436 & 0.781 & 0.557 & 0.446 & 0.068 & 0.900 & 0.678 & 0.187 & 0.488 & 0.337 \\
\hline
\end{tabular}

$601 \quad \mathrm{n}: 9$

602 EP: Energy-protein, SEM: standard error of the mean, IBW: Initial body weight, FBW: Final body weight, BWG: Body weight gain, FI: feed intake, FCR: Feed conversion ratio 
603

604

Table 3 Effect of addition of sepiolite on low energy low protein diets on digestibility of nutrients in broiler

\begin{tabular}{|c|c|c|c|c|c|}
\hline $\begin{array}{l}\text { EP } \\
\text { level }\end{array}$ & $\begin{array}{c}\text { Sepiolite } \\
(\%)\end{array}$ & $\begin{array}{c}\text { DMD } \\
(\%)\end{array}$ & $\begin{array}{c}\text { OMD } \\
(\%)\end{array}$ & $\begin{array}{l}\text { CPD } \\
(\%)\end{array}$ & $\begin{array}{l}\text { VIS }_{\text {ileum }} \\
\text { (cp) }\end{array}$ \\
\hline Normal & & 70.96 & 71.96 & 76.72 & 1.07 \\
\hline \multirow[t]{3}{*}{ Low } & & 64.96 & 66.44 & 71.32 & 1.13 \\
\hline & 0 & 66.42 & 67.74 & 71.58 & 1.22 \\
\hline & 1 & 69.49 & 70.66 & 76.46 & 0.99 \\
\hline Normal & 0 & 69.20 & 70.51 & $75.58^{b}$ & $1.15^{\mathrm{b}}$ \\
\hline Normal & 1 & 72.71 & 73.40 & $77.87^{\mathrm{a}}$ & $1.00^{\mathrm{c}}$ \\
\hline Low & 0 & 63.64 & 64.97 & $67.59^{c}$ & $1.29^{\mathrm{a}}$ \\
\hline Low & 1 & 66.27 & 67.92 & $75.04^{b}$ & $0.97^{\mathrm{c}}$ \\
\hline \multicolumn{2}{|r|}{ SEM } & 0.29 & 0.28 & 0.23 & 0.02 \\
\hline \multicolumn{6}{|c|}{ P-value } \\
\hline & EP level & $<0.001$ & $<0.001$ & $<0.001$ & 0.050 \\
\hline & Sepiolite & $<0.001$ & $<0.001$ & $<0.001$ & $<0.001$ \\
\hline & EP level*Sepiolite & 0.453 & 0.953 & $<0.001$ & 0.007 \\
\hline
\end{tabular}

605

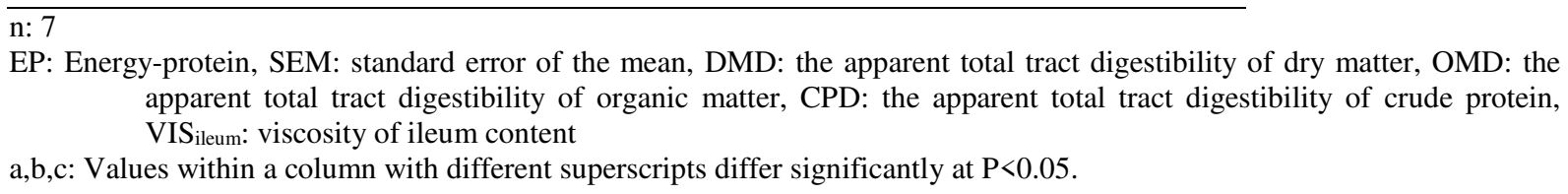
apparent total tract digestibility of organic matter, CPD: the apparent total tract digestibility of crude protein, VIS ileum: viscosity of ileum content

a,b,c: Values within a column with different superscripts differ significantly at $\mathrm{P}<0.05$. 
$\underline{\text { Table } 4 \text { Effect of addition of sepiolite on low energy low protein diets on intestinal histomorphology of broilers }}$

\begin{tabular}{|c|c|c|c|c|c|c|c|c|c|c|c|c|c|c|c|c|}
\hline \multirow[b]{2}{*}{$\begin{array}{l}\mathrm{EP} \\
\text { level }\end{array}$} & \multirow[b]{2}{*}{$\begin{array}{c}\text { Sepiolite } \\
(\%)\end{array}$} & \multicolumn{5}{|c|}{ Duodenum } & \multicolumn{5}{|c|}{ Jejunum } & \multicolumn{5}{|c|}{ Ileum } \\
\hline & & $\begin{array}{l}\text { VH } \\
(\mu \mathrm{m})\end{array}$ & $\begin{array}{l}\text { VW } \\
(\mu \mathrm{m})\end{array}$ & $\begin{array}{c}\mathrm{CD} \\
(\mu \mathrm{m})\end{array}$ & VH/CD & $\begin{array}{c}\text { VSA } \\
\left(\mathrm{mm}^{2}\right)\end{array}$ & $\begin{array}{l}\text { VH } \\
(\mu \mathrm{m})\end{array}$ & $\begin{array}{l}\text { VW } \\
(\mu \mathrm{m})\end{array}$ & $\begin{array}{l}\mathrm{CD} \\
(\mu \mathrm{m})\end{array}$ & VH/CD & $\begin{array}{c}\text { VSA } \\
\left(\mathrm{mm}^{2}\right)\end{array}$ & $\begin{array}{l}\mathrm{VH} \\
(\mu \mathrm{m})\end{array}$ & $\begin{array}{l}\text { VW } \\
(\mu \mathrm{m})\end{array}$ & $\begin{array}{c}\mathrm{CD} \\
(\mu \mathrm{m})\end{array}$ & VH/CD & $\begin{array}{l}\text { VSA } \\
\left(\mathrm{mm}^{2}\right)\end{array}$ \\
\hline \multirow{4}{*}{$\begin{array}{l}\text { Normal } \\
\text { Low }\end{array}$} & & 1272.4 & 183.2 & 205.1 & 6.55 & 0.73 & 836.8 & 171.3 & 186.7 & 4.79 & 0.45 & 586.8 & 184.4 & 141.9 & 4.27 & 0.34 \\
\hline & & 1028.4 & 183.9 & 157.4 & 6.98 & 0.60 & 736.9 & 163.1 & 120.3 & 6.44 & 0.38 & 569.1 & 180.6 & 119.7 & 4.83 & 0.33 \\
\hline & 0 & 1108.1 & 178.9 & 188.3 & 6.22 & 0.63 & 754.5 & 165.9 & 157.0 & 5.17 & 0.40 & 554.9 & 189.2 & 131.6 & 4.31 & 0.33 \\
\hline & 1 & 1192.7 & 188.2 & 174.3 & 7.31 & 0.70 & 819.3 & 168.5 & 150.0 & 6.06 & 0.44 & 601.1 & 175.8 & 130.1 & 4.79 & 0.33 \\
\hline \multirow{5}{*}{$\begin{array}{l}\text { Normal } \\
\text { Normal } \\
\text { Low } \\
\text { Low }\end{array}$} & 0 & $1272.7^{\mathrm{a}}$ & $189.5^{\mathrm{ab}}$ & $200.8^{\mathrm{ab}}$ & $6.61^{\mathrm{b}}$ & $0.76^{\mathrm{a}}$ & 823.9 & 174.5 & 188.3 & $4.64^{c}$ & 0.45 & $583.3^{\mathrm{a}}$ & 190.2 & 140.8 & $4.24^{\mathrm{b}}$ & 0.35 \\
\hline & 1 & $1272.1^{\mathrm{a}}$ & $177.0^{\mathrm{b}}$ & $209.4^{\mathrm{a}}$ & $6.49^{b}$ & $0.71^{\mathrm{a}}$ & 849.7 & 168.1 & 185.1 & $4.95^{\mathrm{bc}}$ & 0.45 & $590.3^{\mathrm{a}}$ & 178.6 & 143.1 & $4.30^{\mathrm{b}}$ & 0.33 \\
\hline & 0 & $943.5^{c}$ & $168.3^{b}$ & $175.7^{\mathrm{b}}$ & $5.82^{\mathrm{b}}$ & $0.50^{\mathrm{b}}$ & 685.0 & 157.3 & 125.6 & $5.70^{\mathrm{b}}$ & 0.34 & $526.4^{\mathrm{b}}$ & 188.2 & 122.3 & $4.38^{\mathrm{b}}$ & 0.32 \\
\hline & 1 & $1113.3^{\mathrm{b}}$ & $199.4^{\mathrm{a}}$ & $139.2^{\mathrm{c}}$ & $8.14^{\mathrm{a}}$ & $0.70^{\mathrm{a}}$ & 788.8 & 168.8 & 115.0 & $7.18^{\mathrm{a}}$ & 0.42 & $611.9^{\mathrm{a}}$ & 173.0 & 117.1 & $5.27^{\mathrm{a}}$ & 0.34 \\
\hline & SEM & 13.9 & 3.8 & 4.6 & 0.16 & 0.02 & 11.8 & 4.1 & 4.5 & 0.14 & 0.01 & 8.0 & 3.8 & 2.4 & 0.09 & 0.01 \\
\hline & & \multicolumn{15}{|c|}{ P-value } \\
\hline & EP level & $<0.001$ & 0.936 & $<0.001$ & 0.190 & $<0.001$ & $<0.001$ & 0.314 & $<0.001$ & $<0.001$ & 0.008 & 0.271 & 0.621 & $<0.001$ & 0.001 & 0.466 \\
\hline & Sepiolite & 0.003 & 0.229 & 0.131 & 0.001 & 0.038 & 0.007 & 0.755 & 0.438 & 0.002 & 0.146 & 0.005 & 0.083 & 0.758 & 0.006 & 0.971 \\
\hline \multicolumn{2}{|c|}{ EP level*Sepiolite } & 0.003 & 0.005 & 0.016 & $<0.001$ & $<0.001$ & 0.101 & 0.273 & 0.677 & 0.046 & 0.132 & 0.015 & 0.817 & 0.434 & 0.017 & 0.284 \\
\hline
\end{tabular}

EP: Energy-protein, SEM: standard error of the mean, VH: villus height, VW: villus width, CD: crypt depth, VSA: villus surface area

a,b,c: Values within a column with different superscripts differ significantly at $\mathrm{P}<0.05$. 
640 Table 5 Effect of addition of sepiolite on low energy low protein diets on carcass yield and some relative organ weights in broilers

\begin{tabular}{|c|c|c|c|c|c|c|c|c|}
\hline $\begin{array}{l}\text { EP } \\
\text { level }\end{array}$ & $\begin{array}{c}\text { Sepiolite } \\
(\%)\end{array}$ & $\begin{array}{c}\text { Carcass yield } \\
(\%)\end{array}$ & $\begin{array}{c}\text { Liver } \\
(\%)\end{array}$ & $\begin{array}{c}\text { Heart } \\
(\%)\end{array}$ & $\begin{array}{l}\text { Gizzard } \\
(\%)\end{array}$ & $\begin{array}{c}\text { Spleen } \\
(\%)\end{array}$ & $\begin{array}{c}\text { Bursa } \\
\text { Fabricius }(\%)\end{array}$ & $\begin{array}{l}\text { Abdominal fat } \\
(\%)\end{array}$ \\
\hline Normal & & 74.37 & 1.74 & 0.53 & 1.72 & 0.12 & 0.19 & 1.00 \\
\hline Low & & 74.43 & 1.72 & 0.52 & 1.64 & 0.13 & 0.18 & 1.23 \\
\hline & 0 & 74.41 & 1.76 & 0.54 & 1.66 & 0.13 & 0.18 & 1.20 \\
\hline & 1 & 74.39 & 1.70 & 0.51 & 1.70 & 0.12 & 0.18 & 1.03 \\
\hline Normal & 0 & 74.30 & $1.72^{\mathrm{ab}}$ & 0.54 & 1.69 & 0.13 & 0.19 & 1.14 \\
\hline Normal & 1 & 74.45 & $1.76^{\mathrm{ab}}$ & 0.52 & 1.76 & 0.12 & 0.19 & 0.86 \\
\hline Low & 0 & 74.53 & $1.80^{\mathrm{a}}$ & 0.54 & 1.64 & 0.13 & 0.18 & 1.26 \\
\hline Low & 1 & 74.32 & $1.65^{\mathrm{b}}$ & 0.51 & 1.65 & 0.13 & 0.18 & 1.20 \\
\hline & $\mathrm{M}$ & 0.12 & 0.02 & 0.01 & 0.02 & 0.00 & 0.01 & 0.05 \\
\hline \multicolumn{9}{|c|}{ P-value } \\
\hline & EP level & 0.837 & 0.679 & 0.788 & 0.062 & 0.850 & 0.397 & 0.024 \\
\hline & Sepiolite & 0.913 & 0.194 & 0.274 & 0.345 & 0.623 & 0.854 & 0.095 \\
\hline EP lev & *Sepiolite & 0.460 & 0.024 & 0.958 & 0.466 & 0.616 & 0.780 & 0.273 \\
\hline
\end{tabular}

\footnotetext{
641 n: 18 EP: Energy-protein, SEM: standard error of the mean,
}

643 a,b: Values within a column with different superscripts differ significantly at $\mathrm{P}<0.05$. 
645 Table 6 Effect of addition of sepiolite on low energy low protein diets on breast meat characteristics of broilers

\begin{tabular}{|c|c|c|c|c|c|c|c|c|c|c|c|}
\hline $\begin{array}{l}\text { EP } \\
\text { level }\end{array}$ & $\begin{array}{c}\text { Sepiolite } \\
(\%)\end{array}$ & $\begin{array}{c}\text { WHC } \\
(\%)\end{array}$ & $\begin{array}{l}\text { CL } \\
(\%)\end{array}$ & $\begin{array}{l}\text { TAS } \\
(\%)\end{array}$ & $\begin{array}{l}\text { TOS } \\
(\%)\end{array}$ & $\begin{array}{l}\text { OSI } \\
(\%)\end{array}$ & $\begin{array}{l}\text { CAT } \\
(\mathrm{U} / \mathrm{l})\end{array}$ & $\begin{array}{l}\text { DM } \\
(\%)\end{array}$ & $\begin{array}{l}\text { Ash } \\
(\%)\end{array}$ & $\begin{array}{l}\mathrm{CP} \\
(\%)\end{array}$ & $\begin{array}{l}\mathrm{EE} \\
(\%)\end{array}$ \\
\hline Normal & & 24.83 & 20.98 & 0.62 & 3.04 & 0.51 & 213.06 & 26.68 & 1.14 & 24.32 & 1.22 \\
\hline Low & & 24.01 & 21.36 & 0.48 & 3.57 & 0.77 & 178.56 & 26.83 & 1.16 & 24.32 & 1.35 \\
\hline & 0 & 24.15 & 21.43 & 0.52 & 3.35 & 0.68 & 187.72 & 26.73 & 1.15 & 24.29 & 1.29 \\
\hline & 1 & 24.69 & 20.91 & 0.58 & 3.26 & 0.61 & 203.89 & 26.78 & 1.15 & 24.36 & 1.27 \\
\hline Normal & 0 & 24.70 & 21.28 & 0.59 & 3.15 & 0.54 & 204.00 & 26.67 & 1.13 & 24.32 & 1.22 \\
\hline Normal & 1 & 24.96 & 20.69 & 0.64 & 2.93 & 0.49 & 222.11 & 26.69 & 1.15 & 24.33 & 1.21 \\
\hline Low & 0 & 23.61 & 21.59 & 0.45 & 3.54 & 0.81 & 171.44 & 26.78 & 1.16 & 24.26 & 1.36 \\
\hline Low & 1 & 24.41 & 21.14 & 0.51 & 3.59 & 0.72 & 185.67 & 26.87 & 1.15 & 24.38 & 1.33 \\
\hline \multicolumn{2}{|c|}{ SEM } & 0.10 & 0.09 & 0.02 & 0.10 & 0.03 & 11.62 & 0.09 & 0.01 & 0.08 & 0.03 \\
\hline \multicolumn{2}{|c|}{ Nivi } & \\
\hline & EP level & \multicolumn{10}{|c|}{$\frac{\text { P-value }}{20001}$} \\
\hline & Sepiolite & 0.009 & 0.009 & 0.147 & 0.663 & 0.194 & 0.492 & 0.756 & 0.736 & 0.690 & 0.803 \\
\hline EP lev & *Sepiolite & 0.162 & 0.738 & 0.944 & 0.525 & 0.698 & 0.934 & 0.862 & 0.433 & 0.749 & 0.929 \\
\hline
\end{tabular}

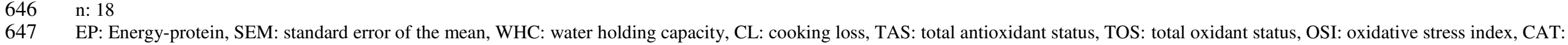

648 catalase, DM: dry matter, CP: crude protein, EE: ether extract 
Table 7 Effect of addition of sepiolite on low energy low protein diets on some blood serum biochemical indices in broilers

\begin{tabular}{|c|c|c|c|c|c|c|c|c|c|}
\hline $\begin{array}{l}\text { EP } \\
\text { level }\end{array}$ & $\begin{array}{c}\text { Sepiolite } \\
(\%)\end{array}$ & $\begin{array}{l}\mathrm{TP} \\
(\mathrm{g} / \mathrm{l})\end{array}$ & $\begin{array}{l}\text { ALB } \\
(\mathrm{g} / \mathrm{l})\end{array}$ & $\begin{array}{c}\mathrm{UA} \\
(\mathrm{mg} / \mathrm{dl})\end{array}$ & $\begin{array}{l}\text { CHOL } \\
(\mathrm{mg} / \mathrm{dl})\end{array}$ & $\begin{array}{c}\mathrm{TG} \\
(\mathrm{mg} / \mathrm{dl})\end{array}$ & $\begin{array}{l}\text { ALT } \\
(\mathrm{U} / \mathrm{l})\end{array}$ & $\begin{array}{l}\text { AST } \\
\text { (U/l) }\end{array}$ & $\begin{array}{l}\text { ALP } \\
\text { (U/1) }\end{array}$ \\
\hline Normal & & 25.90 & 11.55 & 3.83 & 69.32 & 65.42 & 46.00 & 158.44 & 759.22 \\
\hline Low & & 22.82 & 10.84 & 3.66 & 55.81 & 58.87 & 40.39 & 137.89 & 733.67 \\
\hline & 0 & 23.13 & 10.89 & 3.78 & 66.54 & 66.04 & 43.31 & 147.89 & 741.00 \\
\hline & 1 & 25.59 & 11.51 & 3.71 & 58.59 & 58.25 & 43.08 & 148.44 & 751.89 \\
\hline Normal & 0 & 24.28 & $10.88^{b}$ & 3.87 & $75.63^{\mathrm{a}}$ & 69.27 & 46.37 & 159.00 & 746.00 \\
\hline Normal & 1 & 27.52 & $12.22^{\mathrm{a}}$ & 3.80 & $63.01^{\mathrm{b}}$ & 61.58 & 45.63 & 157.89 & 772.44 \\
\hline Low & 0 & 21.98 & $10.89^{b}$ & 3.70 & $57.46^{c}$ & 62.82 & 40.26 & 136.78 & 736.00 \\
\hline Low & 1 & 23.66 & $10.79^{b}$ & 3.62 & $54.17^{c}$ & 54.91 & 40.52 & 139.00 & 731.33 \\
\hline & SEM & 0.32 & 0.10 & 0.08 & 0.88 & 1.06 & 0.66 & 2.45 & 12.75 \\
\hline \multicolumn{10}{|c|}{ P-value } \\
\hline & EP leve & $<0.001$ & 0.001 & 0.252 & $<0.001$ & 0.004 & $<0.001$ & $<0.001$ & 0.324 \\
\hline & Sepiolit & 0.001 & 0.003 & 0.624 & $<0.001$ & 0.001 & 0.861 & 0.910 & 0.672 \\
\hline EP & evel*Sepiolit & 0.235 & 0.001 & 0.985 & 0.013 & 0.959 & 0.709 & 0.736 & 0.546 \\
\hline
\end{tabular}

0.985

0.013

0.959

0.709

0.736

0.546

EP: Energy-protein, SEM: standard error of the mean, TP: total protein, ALB: albumin, UA: uric acid, CHOL: cholesterol, TG: triglyceride, ALT: alanine transaminase, AST: aspartate transaminase, ALP: alkaline phosphatase

a,b,c: Values within a column with different superscripts differ significantly at $\mathrm{P}<0.05$. 
Table 8 Effect of addition of sepiolite on low energy low protein diets on some blood minerals in broilers

\begin{tabular}{|c|c|c|c|c|c|c|c|c|c|}
\hline $\begin{array}{l}\text { EP } \\
\text { level }\end{array}$ & $\begin{array}{c}\text { Sepiolite } \\
(\%)\end{array}$ & $\begin{array}{c}\mathrm{Ca} \\
(\mathrm{mg} / \mathrm{dl})\end{array}$ & $\mathrm{P}(\mathrm{mg} / \mathrm{dl})$ & $\begin{array}{c}\mathrm{Na} \\
(\mathrm{mg} / \mathrm{l})\end{array}$ & $\begin{array}{c}\mathrm{K} \\
(\mathrm{mg} / \mathrm{l})\end{array}$ & $\begin{array}{c}\mathrm{Mg} \\
(\mathrm{mg} / \mathrm{dl})\end{array}$ & $\begin{array}{c}\mathrm{Zn} \\
(\mathrm{mg} / \mathrm{dl})\end{array}$ & $\begin{array}{c}\mathrm{Cu} \\
(\mathrm{mg} / \mathrm{l})\end{array}$ & $\mathrm{Fe}(\mathrm{mg} / \mathrm{l})$ \\
\hline Normal & & 7.73 & 5.22 & 126.44 & 3.06 & 2.04 & 2.17 & 0.64 & 3.51 \\
\hline Low & & 7.29 & 5.04 & 125.78 & 3.00 & 1.93 & 2.05 & 0.64 & 3.56 \\
\hline & 0 & 7.33 & 5.01 & 126.56 & 3.05 & 2.02 & 2.07 & 0.67 & 3.54 \\
\hline & 1 & 7.69 & 5.24 & 125.67 & 3.00 & 1.95 & 2.16 & 0.62 & 3.54 \\
\hline Normal & 0 & 7.55 & 5.08 & 127.00 & 3.09 & 2.04 & 2.15 & 0.68 & 3.48 \\
\hline Normal & 1 & 7.92 & 5.35 & 125.89 & 3.02 & 2.03 & 2.19 & 0.60 & 3.55 \\
\hline Low & 0 & 7.10 & 4.94 & 126.11 & 3.01 & 1.99 & 1.98 & 0.66 & 3.60 \\
\hline Low & 1 & 7.47 & 5.14 & 125.44 & 2.98 & 1.87 & 2.13 & 0.63 & 3.52 \\
\hline & & 0.10 & 0.06 & 1.76 & 0.04 & 0.04 & 0.04 & 0.04 & 0.04 \\
\hline \multicolumn{10}{|c|}{ P-valu } \\
\hline & EP leve & 0.026 & 0.150 & 0.851 & 0.398 & 0.169 & 0.111 & 0.989 & 0.576 \\
\hline & Sepiolit & 0.064 & 0.063 & 0.802 & 0.452 & 0.390 & 0.210 & 0.485 & 0.985 \\
\hline EP 1 & 1*Sepiolit & 0.991 & 0.784 & 0.950 & 0.801 & 0.456 & 0.439 & 0.753 & 0.404 \\
\hline
\end{tabular}

n: 18
EP: Energy-protein, SEM: standard error of the mean 